\title{
Solar Hydrogen Production Coupled with the Degradation of a Dye Pollutant Using $\mathrm{TiO}_{2}$ Modified with Platinum and Nafion
}

\author{
Jungwon Kim, ${ }^{1}$ Yiseul Park, ${ }^{2}$ and Hyunwoong Park ${ }^{3}$ \\ ${ }^{1}$ Department of Environmental Sciences and Biotechnology, Hallym University, Chuncheon, Gangwon-do 200-702, Republic of Korea \\ ${ }^{2}$ Energy Research Division, Daegu Gyeongbuk Institute of Science \& Technology, Daegu 711-873, Republic of Korea \\ ${ }^{3}$ School of Energy Engineering, Kyungpook National University, Daegu 702-701, Republic of Korea \\ Correspondence should be addressed to Hyunwoong Park; hwp@knu.ac.kr
}

Received 24 July 2014; Revised 12 September 2014; Accepted 15 September 2014; Published 13 October 2014

Academic Editor: Yuexiang Li

Copyright @ 2014 Jungwon Kim et al. This is an open access article distributed under the Creative Commons Attribution License, which permits unrestricted use, distribution, and reproduction in any medium, provided the original work is properly cited.

\begin{abstract}
The simultaneous production of molecular hydrogen $\left(\mathrm{H}_{2}\right)$ and degradation of rhodamine $\mathrm{B}(\mathrm{RhB})$ was successfully achieved using $\mathrm{TiO}_{2}$ modified with platinum and nafion $\left(\mathrm{Pt} / \mathrm{TiO}_{2} / \mathrm{Nf}\right)$ under visible light $(\lambda>420 \mathrm{~nm})$. $\mathrm{Pt} / \mathrm{TiO}_{2} / \mathrm{Nf}$ exhibited high activity for $\mathrm{H}_{2}$ production in the presence of RhB and EDTA as a photosensitizer (also an organic dye pollutant) and an electron donor, respectively. However, the activity of $\mathrm{TiO}_{2}$ modified with either platinum or nafion for $\mathrm{H}_{2}$ production was negligible under the same experimental conditions. The negatively charged nafion layer enhances the adsorption of cationic RhB and pulls protons, a source of hydrogen, to the surface of $\mathrm{TiO}_{2}$ through electrostatic attraction. On the other hand, platinum deposits on $\mathrm{TiO}_{2}$ can act as an electron sink and a temporary electron reservoir for the reduction of protons. With the production of $\mathrm{H}_{2}$, $\mathrm{RhB}$ was gradually degraded through $N$-deethylation, which was confirmed by the spectral blue shift of the maximum absorption wavelength $\left(\lambda_{\max }\right)$ from 556 to $499 \mathrm{~nm}$ (corresponding to the $\lambda_{\max }$ of rhodamine 110). With $\mathrm{Pt}_{\mathrm{TiO}} / \mathrm{Nf}$ employed at $[\mathrm{RhB}]=20 \mu \mathrm{M}(0.6 \mu \mathrm{mol})$, approximately $70 \mu \mathrm{mol}$ of $\mathrm{H}_{2}$ was produced and $\mathrm{RhB}$ and its intermediates were completely removed over a $12 \mathrm{~h}$ period. A detailed reaction mechanism was discussed.
\end{abstract}

\section{Introduction}

Dye-sensitized $\mathrm{TiO}_{2}$ systems have been studied extensively for the remediation of environmental pollutants and the production of hydrogen under visible light [1-15]. Both applications are based on photo-induced electron transfer from the dyes to electron acceptors (e.g., pollutants and protons) through the $\mathrm{TiO}_{2}$ conduction band (CB). Although the photonic efficiency of this system is high, expensive synthetic dyes (e.g., Ru-based [1,3-6, 10], (metal) porphyrin [5,7], and engineered organic dyes $[2,8,11-15]$ ) have been primarily used. In addition, most dye-sensitized $\mathrm{TiO}_{2}$ systems suffer from the instability of the dye because dyes can be degraded after electron injection from the excited dye to the $\mathrm{TiO}_{2} \mathrm{CB}$. The high price and low stability of dyes limit the practical applications of dye-sensitized $\mathrm{TiO}_{2}$ systems.

Organic dyes are one of the most serious pollutants in the aquatic environment due to their high production volumes from industry, toxicity, and low biodegradability. The annual global production of organic dyes is approximately one million tons, and a significant amount (10-15\%) of wastewater containing dyes is discharged to the surface water without any treatment $[16,17]$. In addition, some organic dyes are carcinogenic to humans and negatively affect aquatic organisms by interfering with their metabolic processes [1618]. However, the biological treatments widely employed in water treatment are usually inefficient for the degradation of organic dyes [19].

Recently, bifunctional $\mathrm{TiO}_{2}$ photocatalysts have been developed, particularly for simultaneous hydrogen production and pollutant degradation. This bifunctionality was achieved through the surface modification of $\mathrm{TiO}_{2}$ with metal nanoparticles or two different components (i.e., anions and metal nanoparticles) [20-25]. However, the previously developed bifunctional $\mathrm{TiO}_{2}$ photocatalysts worked only under UV light, limiting their practical applications because UV light accounts for only $3 \%$ of natural sunlight at ground level. Visible active photocatalysts can be used to achieve the 
simultaneous hydrogen production and pollutant degradation under visible light [26]. Another approach to addressing this challenge would be to use the organic dyes to be treated as a photosensitizer for hydrogen production instead of expensive synthetic dyes, while simultaneously degrading these organic dyes under visible light (44\% of natural sunlight).

In this work, we successfully achieved the simultaneous production of hydrogen and degradation of rhodamine $\mathrm{B}$ ( $\mathrm{RhB}$, an azo dye that accounts for more than $65 \%$ of total dye production [16]) using $\mathrm{TiO}_{2}$ modified with platinum and nafion $\left(\mathrm{Pt} / \mathrm{TiO}_{2} / \mathrm{Nf}\right)$ under visible light. The effects of various experimental parameters (e.g., initial $\mathrm{pH}\left(\mathrm{pH}_{i}\right)$, $\mathrm{RhB}$ concentration, and EDTA concentration) on $\mathrm{H}_{2}$ production were investigated. In addition, a detailed reaction mechanism for the simultaneous production of hydrogen and degradation of RhB was suggested.

\section{Experimental}

2.1. Materials and Reagents. The materials and reagents were used as received without further purification. These substances include $\mathrm{TiO}_{2}$ powder (Hombikat, UV-100), rhodamine $\mathrm{B}\left(\mathrm{RhB}, \mathrm{C}_{28} \mathrm{H}_{31} \mathrm{ClN}_{2} \mathrm{O}_{3}\right.$, Aldrich), chloroplatinic acid $\left(\mathrm{H}_{2} \mathrm{PtCl}_{6}\right.$, Aldrich), methanol $\left(\mathrm{CH}_{4} \mathrm{O}\right.$, J. T. Baker), nafion perfluorinated resin solution ( $5 \mathrm{wt} \%$ solution in a mixture of alcohol and water, Aldrich), and ethylenediaminetetraacetic acid disodium salt dihydrate (EDTA, $\mathrm{C}_{10} \mathrm{H}_{14} \mathrm{~N}_{2} \mathrm{Na}_{2} \mathrm{O}_{8} \cdot 2 \mathrm{H}_{2} \mathrm{O}$, Aldrich). Ultrapure deionized water $(18.3 \mathrm{M} \Omega \mathrm{cm})$ prepared by a water purification system (Barnstead) was used.

2.2. Catalyst Preparation. Platinum $(\mathrm{Pt})$ nanoparticles were deposited onto the surface of $\mathrm{TiO}_{2}$ using a photodeposition method [27]. An aqueous $\mathrm{TiO}_{2}$ suspension $(0.5 \mathrm{~g} / \mathrm{L}, 500 \mathrm{~mL})$ containing chloroplatinic acid as a Pt precursor $(100 \mu \mathrm{M})$ and methanol as an electron donor $(1 \mathrm{M})$ was irradiated with a $200 \mathrm{~W}$ mercury lamp for $30 \mathrm{~min}$. Next, the Pt-deposited $\mathrm{TiO}_{2}\left(\mathrm{Pt} / \mathrm{TiO}_{2}\right)$ powder was collected by filtration through a $0.45 \mu \mathrm{m}$ PVDF disc filter (Pall), washed with distilled water, and dried in an oven at $70^{\circ} \mathrm{C}$. The typical Pt loading on $\mathrm{TiO}_{2}$ was estimated to be ca. $3 \mathrm{wt} \%$ by measuring the concentration of unused chloroplatinic acid remaining in the filtrate solution after the photodeposition using inductively coupled plasma atomic emission spectroscopy (ICP-AES, Thermo Jarrell Ash Corp.). To obtain $\mathrm{Pt} / \mathrm{TiO}_{2} / \mathrm{Nf}\left(\mathrm{TiO}_{2}\right.$ modified with $\mathrm{Pt}$ and nafion), an aliquot of nafion solution $(0.1 \mathrm{~mL})$ was added to the $\mathrm{Pt} / \mathrm{TiO}_{2}$ powder $(0.1 \mathrm{~g})$, mixed well, and dried at room temperature overnight [28].

2.3. Photocatalysis. The catalyst powder was dispersed in distilled water by sonication for $30 \mathrm{~s}$ in an ultrasonic cleaning bath. An aliquot of the RhB and EDTA stock solution was subsequently added to the suspension to yield the desired initial concentration. The initial $\mathrm{pH}\left(\mathrm{pH}_{i}\right)$ of the suspension was adjusted with $\mathrm{HClO}_{4}$ solution. The total volume of the suspension was $30 \mathrm{~mL}$. Prior to visible light irradiation, $\mathrm{N}_{2}$ gas $(99.9 \%)$ was purged through the suspension for $1 \mathrm{~h}$ to remove dissolved oxygen, and then the reactor was sealed with a rubber septum. A $300 \mathrm{~W}$ Xe arc lamp (Oriel) was used as a light source. Light was passed through a $10 \mathrm{~cm}$ IR water filter and a cutoff filter $(\lambda>420 \mathrm{~nm})$, and then the filtered light was focused onto a cylindrical glass reactor with a quartz window.

2.4. Analysis. The amount of photogenerated molecular hydrogen $\left(\mathrm{H}_{2}\right)$ in the headspace of the reactor was analyzed using a gas chromatograph (GC, HP6890A) equipped with a thermal conductivity detector and a $5 \AA$ molecular sieve column. Sample aliquots were withdrawn from the visiblelight-irradiated reactor and filtered through a $0.45 \mu \mathrm{m}$ PTFE syringe filter (Millipore) to remove catalyst particles prior to the analysis of $\mathrm{RhB}$. The color disappearance of $\mathrm{RhB}$ and its maximum absorption wavelength $\left(\lambda_{\max }\right)$ shift resulting from the stepwise $N$-deethylation [29] were monitored using a UV-visible spectrophotometer (Shimadzu UV-2401PC). It should be noted that $\mathrm{RhB}$ (colored) is transformed to leuco $\mathrm{RhB}$ (colorless) through the addition of $\mathrm{H}^{\bullet}$ (formed from the reduction of $\mathrm{H}^{+}$) in the absence of oxygen, but leuco $\mathrm{RhB}$ is dehydrogenated back to $\mathrm{RhB}$ in the presence of oxygen [30]. To exclude the color disappearance through the formation of leuco $\mathrm{RhB}$, the absorption spectrum of samples was measured after exposure to air. The concentrations of RhB adsorbed on the catalyst surface were calculated by subtracting the equilibrated concentrations (with catalyst, after $30 \mathrm{~min}$ in the dark) from the initial concentrations (without catalyst). The concentration of $\mathrm{RhB}$ was determined by measuring the absorbance at $556 \mathrm{~nm}$.

\section{Results and Discussion}

3.1. Effect of Nafion Coating on $\mathrm{H}_{2}$ Production. RhB, a representative azo dye pollutant, was selected as a photosensitizer, and the production of $\mathrm{H}_{2}$ in the presence of EDTA (electron donor) was compared between $\mathrm{Pt} / \mathrm{TiO}_{2}$ and $\mathrm{Pt} / \mathrm{TiO}_{2} / \mathrm{Nf}$ (Figure 1(a)). The production of $\mathrm{H}_{2}$ in the suspension of $\mathrm{Pt} / \mathrm{TiO}_{2}$ was very low but was markedly enhanced by the nafion coating of $\mathrm{Pt} / \mathrm{TiO}_{2}$.

Under visible light, $\mathrm{RhB}$ adsorbed on the $\mathrm{TiO}_{2}$ surface is excited (see, reaction (1)), and then electrons are transferred from the excited $\mathrm{RhB}$ to protons (or water molecules) through the $\mathrm{TiO}_{2} \mathrm{CB}$ and $\mathrm{Pt}$ nanoparticles (see, reactions (2)-(4)):

$$
\begin{gathered}
\mathrm{RhB}-\mathrm{TiO}_{2}+\text { visible light } \longrightarrow \mathrm{RhB}^{*}-\mathrm{TiO}_{2} \\
\mathrm{RhB}^{*}-\mathrm{TiO}_{2} \longrightarrow \mathrm{RhB}^{\cdot+}-\mathrm{TiO}_{2}\left(\mathrm{e}_{\mathrm{cb}}{ }^{-}\right) \\
\mathrm{TiO}_{2}\left(\mathrm{e}_{\mathrm{cb}}{ }^{-}\right) / \mathrm{Pt} \longrightarrow \mathrm{TiO}_{2} / \mathrm{Pt}\left(\mathrm{e}_{\mathrm{tr}}{ }^{-}\right) \\
\left.\mathrm{Pt}\left(2 \mathrm{e}_{\mathrm{tr}}{ }^{-}\right)+2 \mathrm{H}^{+} \text {(or } 2 \mathrm{H}_{2} \mathrm{O}\right) \longrightarrow \mathrm{H}_{2}\left(+2 \mathrm{OH}^{-}\right)
\end{gathered}
$$

In these processes, $\mathrm{Pt}$ nanoparticles enhance the interfacial electron transfer from the $\mathrm{TiO}_{2} \mathrm{CB}$ to protons as an electron sink (Schottky-barrier electron trapping) and a temporary electron reservoir that enables the two-electron reduction of protons (see, reactions (3) and (4)) $[32,33]$. In the absence of Pt nanoparticles (i.e., in the cases of $\mathrm{TiO}_{2}$ and $\mathrm{TiO}_{2} / \mathrm{Nf}$ ), the production of $\mathrm{H}_{2}$ was negligible (data not shown). The coating of nafion, an anionic perfluorinated polymer with a sulfonate group $\left(-\mathrm{SO}_{3}{ }^{-}\right)$, changes the surface charge of $\mathrm{TiO}_{2}\left(\mathrm{pH}_{\mathrm{zpc}}=6.0[9]\right)$ from positive to negative under 


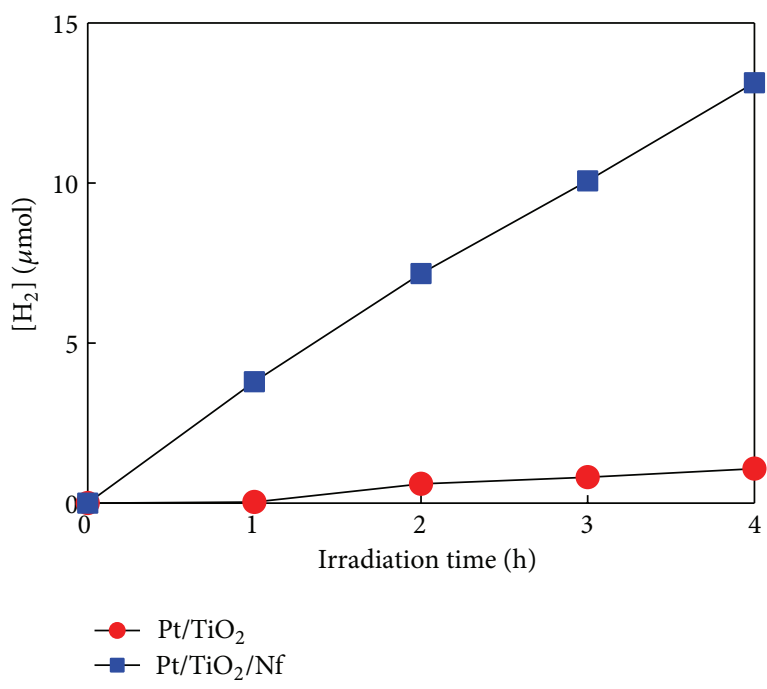

(a)

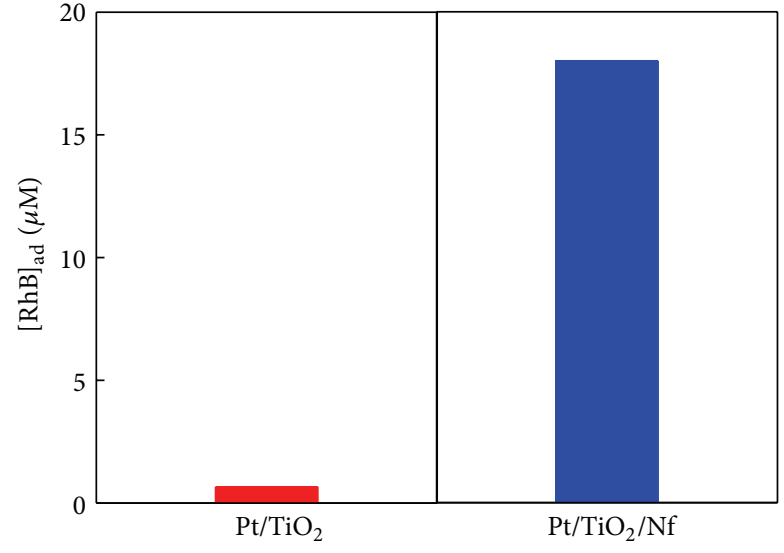

(b)

Figure 1: (a) RhB-sensitized $\mathrm{H}_{2}$ production in the suspension of $\mathrm{Pt} / \mathrm{TiO}_{2}$ and $\mathrm{Pt} / \mathrm{TiO}_{2} / \mathrm{Nf}$. (b) Adsorption of $\mathrm{RhB}$ on the surface of $\mathrm{Pt} / \mathrm{TiO}{ }_{2}$ and $\mathrm{Pt} / \mathrm{TiO}_{2} / \mathrm{Nf}$. Experimental conditions: [catalyst $]=0.5 \mathrm{~g} \mathrm{~L}^{-1},[\mathrm{RhB}]=20 \mu \mathrm{M},[\mathrm{EDTA}]=0.4 \mathrm{mM}, \mathrm{pH}_{i}=5$, and $\lambda>420 \mathrm{~nm}($ for part $(\mathrm{a})$ ).

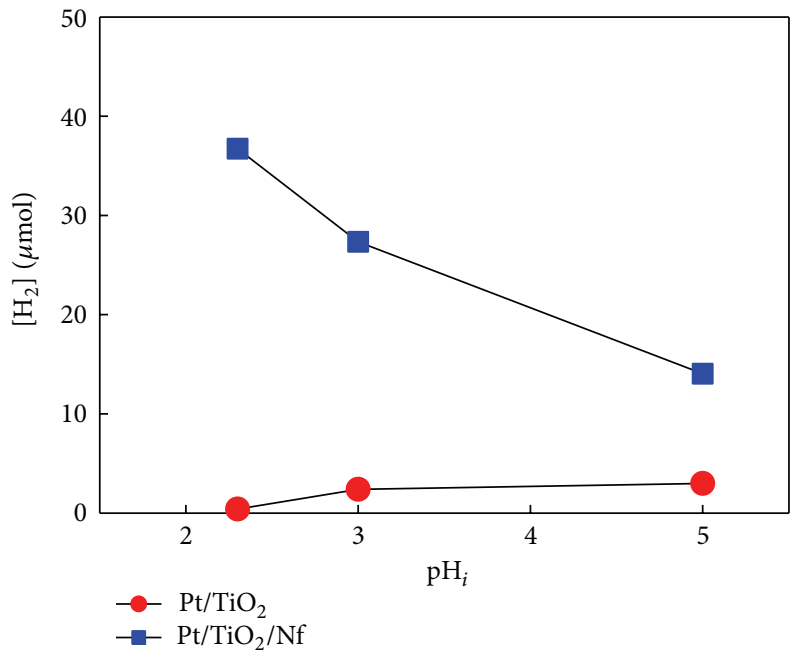

(a)

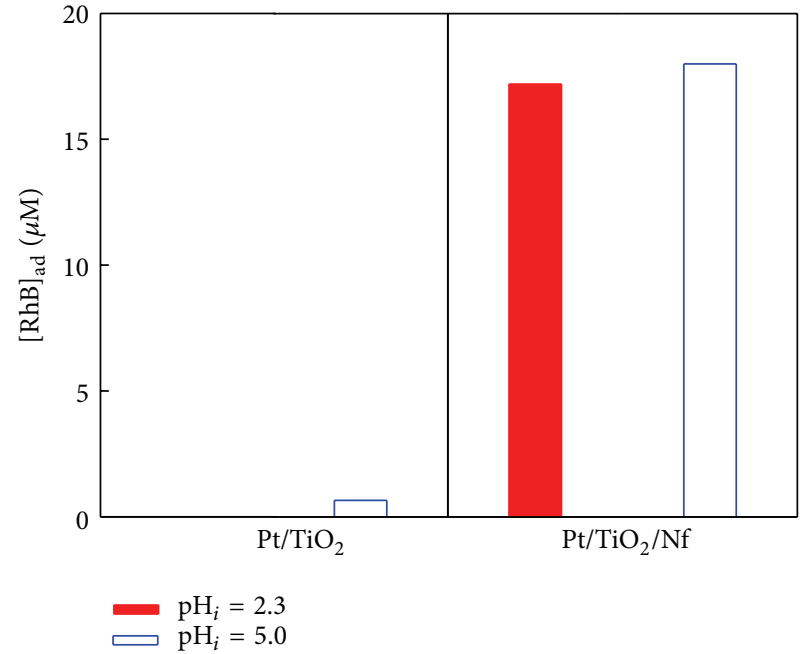

(b)

Figure 2: (a) Production of $\mathrm{H}_{2}$ for $4 \mathrm{~h}$ and (b) adsorption of $\mathrm{RhB}$ in the suspension of $\mathrm{Pt} / \mathrm{TiO}_{2}$ and $\mathrm{Pt} / \mathrm{TiO}_{2} / \mathrm{Nf}_{\text {as a function of } \mathrm{pH}}$. Experimental conditions: [catalyst] $=0.5 \mathrm{~g} \mathrm{~L}^{-1},[\mathrm{RhB}]=40 \mu \mathrm{M}$ (for part (a)) or $20 \mu \mathrm{M}$ (for part (b)), [EDTA] $=4 \mathrm{mM}$, and $\lambda>420 \mathrm{~nm}$ (for part (a)).

acidic conditions $[27,28,34]$. Therefore, the adsorption of cationic $\mathrm{RhB}$ on the $\mathrm{TiO}_{2}$ surface should be enhanced, which accelerates the electron transfer from the excited $\mathrm{RhB}$ to the $\mathrm{TiO}_{2} \mathrm{CB}$ and, eventually, the production of $\mathrm{H}_{2}$.

Figure 1(b) shows the adsorption of $\mathrm{RhB}$ on the surfaces of $\mathrm{Pt} / \mathrm{TiO}_{2}$ and $\mathrm{Pt} / \mathrm{TiO}_{2} / \mathrm{Nf}$ under the same conditions ([RhB] $=20 \mu \mathrm{M}$ and $\mathrm{pH}_{i}=5$ ). The amount of $\mathrm{RhB}$ adsorbed on $\mathrm{Pt} / \mathrm{TiO}_{2}$ was very low $(0.7 \mu \mathrm{M}, 3.5 \%)$ because the positively charged surface of $\mathrm{Pt} / \mathrm{TiO}_{2}$ at $\mathrm{pH}_{i}=5$ repels the cationic $\mathrm{RhB}$ molecules. Under this condition, the interfacial electron transfer from the excited $\mathrm{RhB}$ to the $\mathrm{Pt} / \mathrm{TiO}_{2} \mathrm{CB}$ should be limited. On the other hand, the adsorption of RhB on the surface of $\mathrm{Pt} / \mathrm{TiO}_{2} / \mathrm{Nf}$ was significant $(18.0 \mu \mathrm{M}, 90.0 \%)$ because the negatively charged surface induced by nafion attracts cationic $\mathrm{RhB}$ molecules. This result can help to explain why the production of $\mathrm{H}_{2}$ is markedly enhanced by the nafion coating.

3.2. Effect of Various Parameters on $\mathrm{H}_{2}$ Production. In dyesensitized $\mathrm{TiO}_{2}$ systems, the solution $\mathrm{pH}$ has a significant effect on the production of $\mathrm{H}_{2}$ because the adsorption kinetics of dyes on the $\mathrm{TiO}_{2}$ surface strongly depends on the $\mathrm{pH}$ dependent surface charge of $\mathrm{TiO}_{2}$. Figure 2 shows the production of $\mathrm{H}_{2}$ and the adsorption of $\mathrm{RhB}$ in the suspension of $\mathrm{Pt} / \mathrm{TiO}_{2}$ and $\mathrm{Pt} / \mathrm{TiO}_{2} / \mathrm{Nf}$ as a function of $\mathrm{pH}_{i}$. The $\mathrm{pH}$ dependent $\mathrm{H}_{2}$ production trends for $\mathrm{Pt} / \mathrm{TiO}_{2}$ and $\mathrm{Pt} / \mathrm{TiO}_{2} / \mathrm{Nf}$ 
were opposite: as the $\mathrm{pH}_{i}$ increased, $\mathrm{H}_{2}$ production gradually increased for $\mathrm{Pt} / \mathrm{TiO}_{2}$ but decreased for $\mathrm{Pt} / \mathrm{TiO}_{2} / \mathrm{Nf}$ (Figure 2(a)). However, it should be noted that the $\mathrm{H}_{2}$ production in the suspension of $\mathrm{Pt} / \mathrm{TiO}_{2} / \mathrm{Nf}$ was much higher than that in the suspension of $\mathrm{Pt} / \mathrm{TiO}_{2}$ over the whole $\mathrm{pH}$ range of 2.3 to 5.0.

The surface charge of $\mathrm{Pt} / \mathrm{TiO}_{2}$ is strongly positive at $\mathrm{pH}_{i}=$ 2.3 because most of the surface hydroxyl groups are protonated. Under this condition, the adsorption of cationic RhB on $\mathrm{TiO}_{2}$ should be inhibited, which results in the negligible production of $\mathrm{H}_{2}$. However, the number of surface hydroxyl groups that are not protonated increases as the $\mathrm{pH}$ increases. This makes the surface charge of $\mathrm{TiO}_{2}$ less positive and enables the adsorption of cationic $\mathrm{RhB}$ on $\mathrm{TiO}_{2}$ (see, reaction (5)) and $\mathrm{H}_{2}$ production. As expected, the adsorption of $\mathrm{RhB}$ on the surface of $\mathrm{Pt} / \mathrm{TiO}_{2}$ was negligible at $\mathrm{pH}_{i}=2.3$ but was clearly observed at $\mathrm{pH}_{i}=5.0$, albeit in small amounts (Figure 2(b)):

$$
\begin{aligned}
> & \left.\mathrm{Ti}-\mathrm{OH}_{2}\right]^{(2 / 3)+}+\mathrm{RhB} \\
& \longleftrightarrow>\mathrm{Ti}-\mathrm{OH}]^{(1 / 3)-}-\mathrm{RhB}+\mathrm{H}^{+}
\end{aligned}
$$

$\left(\mathrm{p} K_{a}=3.9\right.$ [35]) (the surface charge of $\mathrm{TiO}_{2}$ is determined by assuming that the surface $\mathrm{Ti}$ having +4 formal charge is located at the octahedral site surrounded by five lattice oxygen atoms and one surface group).

On the other hand, the surface charge of $\mathrm{Pt} / \mathrm{TiO}_{2} / \mathrm{Nf}$ is highly negative, even at acidic $\mathrm{pH}$, because the anionic sulfonate groups $\left(-\mathrm{SO}_{3}{ }^{-}\right)$in the nafion layer outnumber the protonated surface hydroxyl groups of $\left.\mathrm{TiO}_{2}\left(>\mathrm{Ti}-\mathrm{OH}_{2}\right]^{(2 / 3)+}\right)$ $[27,28]$. Therefore, sufficient $\mathrm{RhB}$ to have little effect on $\mathrm{H}_{2}$ production can be adsorbed on the surface of $\mathrm{Pt} / \mathrm{TiO}_{2} / \mathrm{Nf}$ at both $\mathrm{pH}_{i}=2.3$ and 5.0 (Figure 2(b)). Under this condition, the decrease in the production of $\mathrm{H}_{2}$ with increasing $\mathrm{pH}$ implies the existence of another mechanism for $\mathrm{H}_{2}$ production with $\mathrm{Pt} / \mathrm{TiO}_{2} / \mathrm{Nf}$. It has been reported that the concentration of protons in the nafion layer is much higher than that in the aqueous bulk phase due to the electrostatic attraction between the positively charged protons and anionic sulfonate groups [36]. Because the electron transfer from $\mathrm{Pt}$ nanoparticles to protons is kinetically more favorable than that to undissociated water molecules $\left[k\left(\mathrm{e}^{-}+\mathrm{H}_{2} \mathrm{O}\right)=1.9 \times\right.$ $10^{1} \mathrm{M}^{-1} \mathrm{~s}^{-1}$ and $k\left(\mathrm{e}^{-}+\mathrm{H}^{+}\right)=2.3 \times 10^{10} \mathrm{M}^{-1} \mathrm{~s}^{-1}$ ] [37], the locally concentrated protons within the nafion layer provide good conditions for $\mathrm{H}_{2}$ production. At lower $\mathrm{pH}$, more protons can be trapped within the nafion layer, which enhances the electron transfer from Pt nanoparticles to protons. Therefore, the production of $\mathrm{H}_{2}$ with $\mathrm{Pt} / \mathrm{TiO}_{2} / \mathrm{Nf}$ increases as the $\mathrm{pH}$ decreases, in contrast to the case of $\mathrm{Pt} / \mathrm{TiO}_{2}$. Overall, the nafion-enhanced $\mathrm{H}_{2}$ production in the $\mathrm{RhB}$-sensitized $\mathrm{Pt} /$ $\mathrm{TiO}_{2} / \mathrm{Nf}$ system is ascribed to two factors. First, the negatively charged nafion layer enhances the adsorption of cationic RhB. Second, protons, which are more favorably reduced to $\mathrm{H}_{2}$ than undissociated water molecules, are concentrated within the nafion layer.

Figure 3 shows the effect of RhB and EDTA concentrations on the production of $\mathrm{H}_{2}$ in the suspension of $\mathrm{Pt} / \mathrm{TiO}_{2} /$ Nf. The production of $\mathrm{H}_{2}$ was negligible in the absence of either RhB or EDTA, which clearly indicates that RhB and EDTA act as a photosensitizer and an electron donor in the $\mathrm{RhB}$-sensitized $\mathrm{Pt} / \mathrm{TiO}_{2} / \mathrm{Nf}$ system, respectively. The production of $\mathrm{H}_{2}$ rapidly increased with increasing $\mathrm{RhB}$ and EDTA concentrations and then saturated at $[\mathrm{RhB}]=10 \mu \mathrm{M}$ and [EDTA $]=2 \mathrm{mM}$.

The fact that $\mathrm{H}_{2}$ was not produced in the absence of EDTA (electron donor) indicates that the electron transfer from the $\mathrm{TiO}_{2} \mathrm{CB}$ to $\mathrm{RhB}^{\circ+}$ (i.e., charge recombination, reaction (6)) is much faster than that from the $\mathrm{TiO}_{2} \mathrm{CB}$ to Pt nanoparticles (see, reaction (3)), which is consistent with other dye-sensitized $\mathrm{TiO}_{2}$ systems using expensive synthetic dyes for $\mathrm{H}_{2}$ production $[3,7]$. However, EDTA can prevent the charge recombination process by regenerating $\mathrm{RhB}^{\circ+}$ to $\mathrm{RhB}$ (i.e., electron transfer from EDTA to $\mathrm{RhB}^{\circ+}$, reaction (7)), which enables the electron transfer from the $\mathrm{TiO}_{2} \mathrm{CB}$ to Pt nanoparticles and, eventually, the production of $\mathrm{H}_{2}$ :

$$
\begin{aligned}
& \mathrm{RhB}^{\bullet+}-\mathrm{TiO}_{2}\left(\mathrm{e}_{\mathrm{cb}}{ }^{-}\right) \longrightarrow \mathrm{RhB}-\mathrm{TiO}_{2} \\
& \mathrm{EDTA}+\mathrm{RhB}^{\bullet+}-\mathrm{TiO}_{2}\left(\mathrm{e}_{\mathrm{cb}}{ }^{-}\right) \\
& \longrightarrow \mathrm{EDTA}^{\bullet+}+\mathrm{RhB}^{-\mathrm{TiO}_{2}}\left(\mathrm{e}_{\mathrm{cb}}{ }^{-}\right)
\end{aligned}
$$

3.3. Mechanism of RhB Degradation. The stability of dye molecules is an important parameter for the evaluation of dye-sensitized $\mathrm{TiO}_{2}$ systems using expensive synthetic dyes. On the other hand, the degradation of dye during the course of $\mathrm{H}_{2}$ production should increase the utility of dyesensitized $\mathrm{TiO}_{2}$ systems if organic dye pollutants are used as a photosensitizer. This is conceptually similar to bifunctional photocatalysis (i.e., the simultaneous production of hydrogen and degradation of pollutants) [20-26].

Figure 4 shows the absorption spectral change (i.e., degradation) of $\mathrm{RhB}$ in the suspension of $\mathrm{Pt} / \mathrm{TiO}_{2}$ and $\mathrm{Pt} / \mathrm{TiO}_{2} / \mathrm{Nf}$ as a function of irradiation time. In accordance with the absence of $\mathrm{H}_{2}$ production with $\mathrm{Pt} / \mathrm{TiO}_{2}$ at $\mathrm{pH}_{i}=$ 2.3 (Figure 2(a)), the degradation of $\mathrm{RhB}$ was negligible (Figure 4(a)). On the other hand, with $\mathrm{Pt} / \mathrm{TiO}_{2} / \mathrm{Nf}$, the intensity of the RhB absorption spectrum decreased and its position shifted to shorter wavelengths with irradiation time (Figure 4(b)). This result clearly indicates that $\mathrm{RhB}$ is degraded with $\mathrm{H}_{2}$ production in the suspension of $\mathrm{Pt} / \mathrm{TiO}_{2} / \mathrm{Nf}$.

Some dyes including $\mathrm{RhB}$ can be degraded through two pathways: the cleavage of the chromophoric ring and $N$-dealkylation $[29,38,39]$. Between these pathways, the cleavage of the chromophoric ring is not favored under our experimental conditions (i.e., in the absence of oxygen) because it is primarily initiated by the reaction between reactive oxygen species (e.g., $\mathrm{O}_{2}{ }^{--}$and ${ }^{\bullet} \mathrm{OH}$ ) and $\mathrm{RhB}^{\cdot+}$ in the bulk phase $[29,38]$. On the other hand, it has been reported that the $N$-deethylation proceeds through the electron transfer from $\mathrm{RhB}$ to the $\mathrm{TiO}_{2} \mathrm{CB}$ and subsequent hydrolysis of $\mathrm{RhB}^{\circ+}$ [29], leading to a blue shift of the maximum absorption wavelength $\left(\lambda_{\max }\right)$ because $N$-de-ethylated RhB intermediates exhibit $\lambda_{\max }$ at shorter wavelengths than $\operatorname{RhB}\left(\lambda_{\max }=556 \mathrm{~nm}\right)[29$, 38]. With $\mathrm{Pt} / \mathrm{TiO}_{2} / \mathrm{Nf}$, the $\lambda_{\max }$ shifted from 556 to $502 \mathrm{~nm}$ after $4 \mathrm{~h}$ of visible light irradiation. This significant spectral 


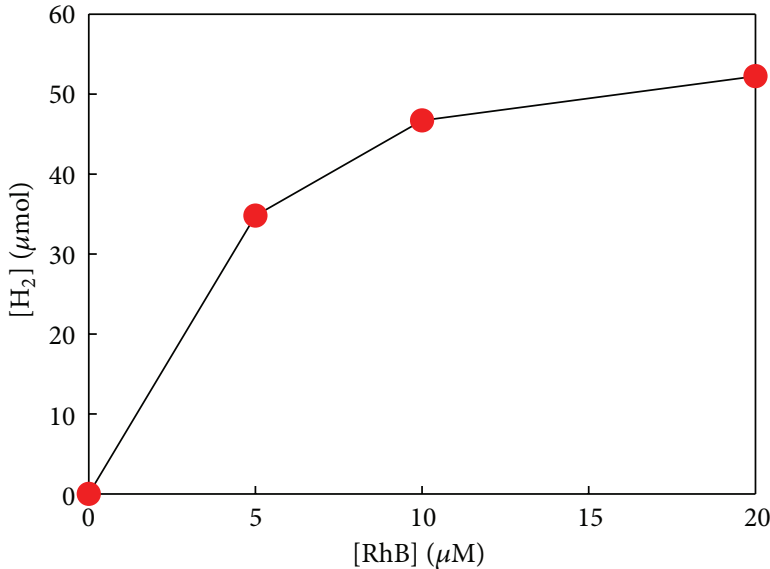

(a)

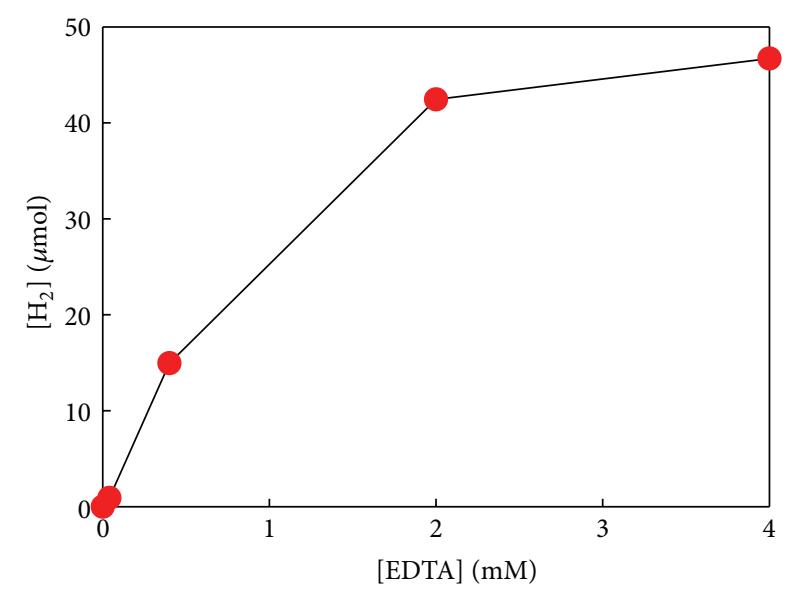

(b)

FIgURE 3: Time-profiled $\mathrm{H}_{2}$ production in the suspension of $\mathrm{Pt} / \mathrm{TiO}_{2} / \mathrm{Nf}$ as a function of (a) $\mathrm{RhB}$ and (b) EDTA concentration. Experimental conditions: $[$ catalyst $]=0.5 \mathrm{~g} \mathrm{~L}^{-1},[\mathrm{EDTA}]=4 \mathrm{mM}$ (for part (a)), $[\mathrm{RhB}]=10 \mu \mathrm{M}$ (for part (b)), $\mathrm{pH}_{i}=2.3$, and $\lambda>420 \mathrm{~nm}$.

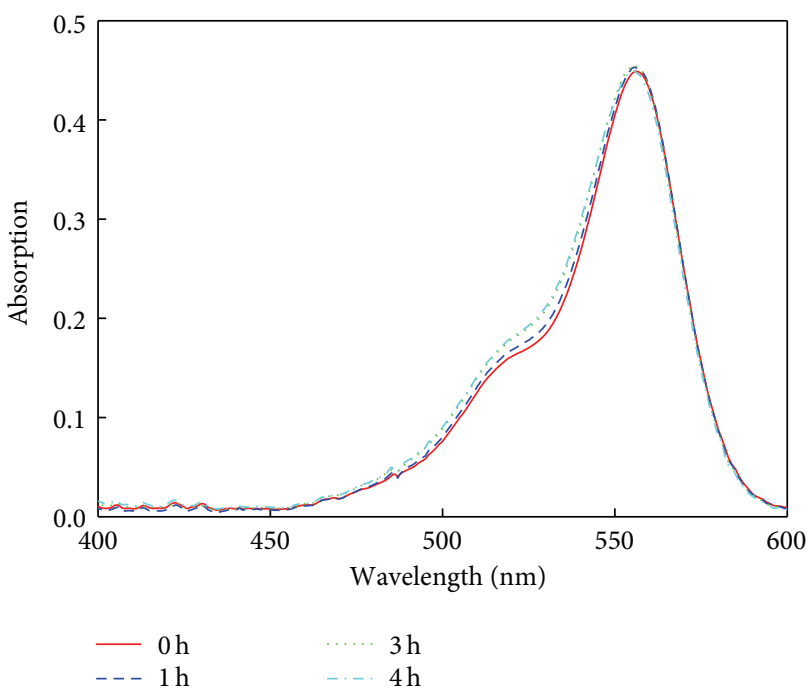

(a)

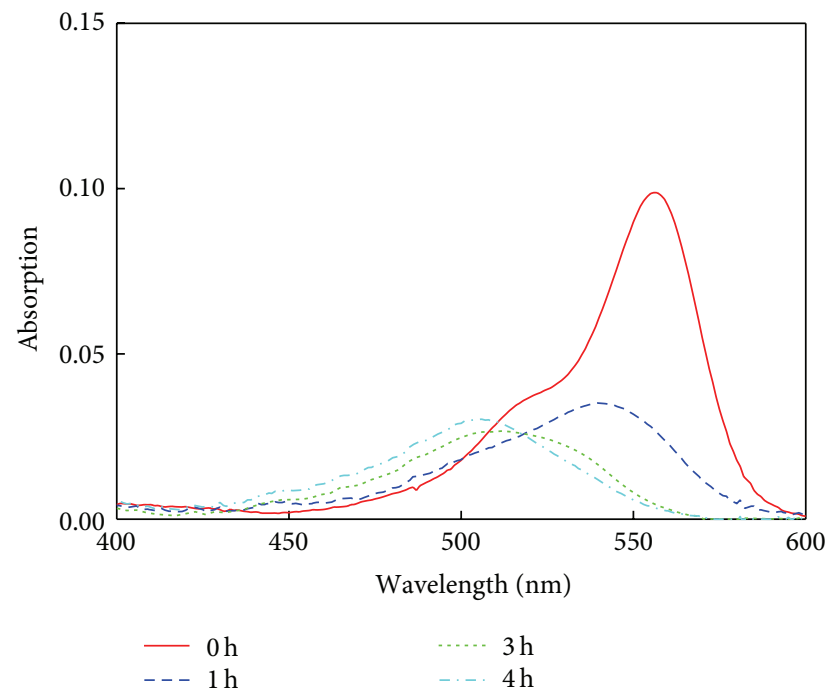

(b)

Figure 4: Absorption spectral change of $\mathrm{RhB}$ in the suspension of (a) $\mathrm{Pt} / \mathrm{TiO}_{2}$ and (b) $\mathrm{Pt} / \mathrm{TiO}_{2} / \mathrm{Nf}$ as a function of irradiation time. Experimental conditions: [catalyst] $=0.5 \mathrm{~g} \mathrm{~L}^{-1},[\mathrm{RhB}]=20 \mu \mathrm{M}$, [EDTA] $=4 \mathrm{mM}, \mathrm{pH}_{i}=2.3$, and $\lambda>420 \mathrm{~nm}$. Samples were diluted by 3 times for the analysis.

shift of $\lambda_{\max }\left(\Delta \lambda_{\max }\right)$ clearly indicates that the degradation of $\mathrm{RhB}$ is primarily initiated by $N$-deethylation.

$\mathrm{RhB}$ was not degraded in the absence of EDTA (data not shown), which implies that $\mathrm{EDTA}^{\circ+}$, not the hydrolysis of $\mathrm{RhB}^{*+}$, plays a critical role in the $N$-deethylation of $\mathrm{RhB}$ in our system. This seems to be because the $N$-deethylation through the hydrolysis of $\mathrm{RhB}^{\circ+}$ is much slower than the reduction of $\mathrm{RhB}^{\circ+}$ by the $\mathrm{TiO}_{2} \mathrm{CB}$ electron (see, reaction (6)) in the absence of oxygen. In this situation, the $\mathrm{N}$-deethylation of $\mathrm{RhB}$ should be due to the oxidation of $\mathrm{RhB}$ (or more preferentially $\mathrm{RhB}^{\circ+}$ ) by EDTA ${ }^{\circ+}$ (see, reaction $(8)$ ) generated from the oxidation of EDTA by $\mathrm{RhB}^{\circ+}$ (see, reaction (7)):

$$
\mathrm{EDTA}^{\bullet+}+\mathrm{RhB}^{\bullet+}-\mathrm{TiO}_{2}\left(\mathrm{e}_{\mathrm{cb}}{ }^{-}\right)
$$

$$
\begin{aligned}
\longrightarrow & \text { EDTA }+N \text {-de-ethylated } \mathrm{RhB} \text { intermediate } \\
& +\mathrm{TiO}_{2}\left(\mathrm{e}_{\mathrm{cb}}{ }^{-}\right)
\end{aligned}
$$

It has been reported that $\mathrm{EDTA}^{\cdot+}$ can oxidize $N, N, N^{\prime}, N^{\prime}$ tetramethyl-p-phenylenediamine (TMPD), which has electron-donating alkyl groups [40]. Likewise, EDTA ${ }^{\circ+}$ could react with the ethyl group of $\mathrm{RhB}^{\circ+}$ to generate $\mathrm{N}$-de-ethylated $\mathrm{RhB}$ intermediates. It should be noted that $\mathrm{RhB}$ is regenerated when $\mathrm{RhB}^{\circ+}$ accepts one electron from the $\mathrm{TiO}_{2}$ CB or EDTA (see, reactions (6) and (7)). However, $N$-de-ethylated RhB intermediates generated by further oxidation of $\mathrm{RhB}^{*+}$ (see, reaction (8)) should not be regenerated to $\mathrm{RhB}$ and undergo further degradation. 


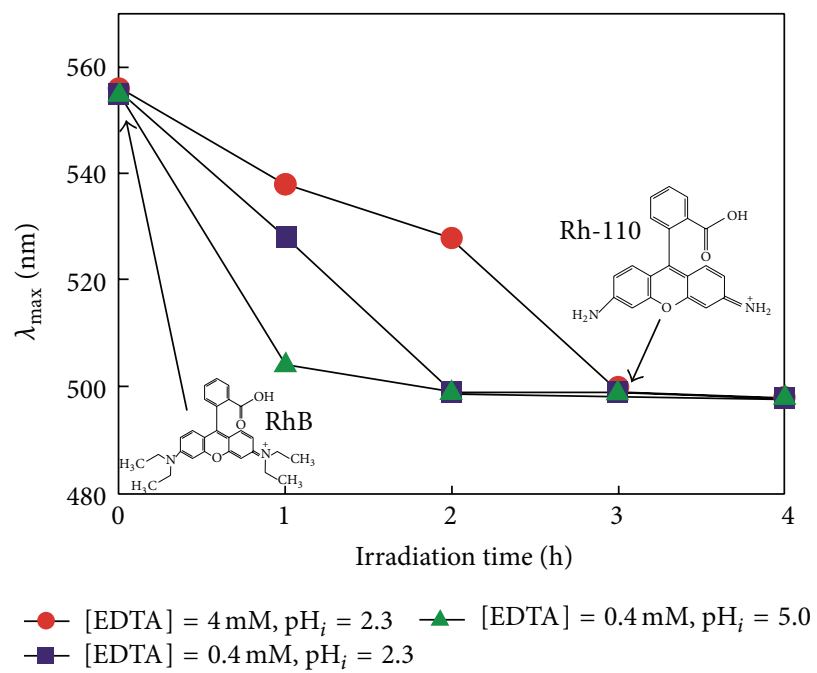

(a)

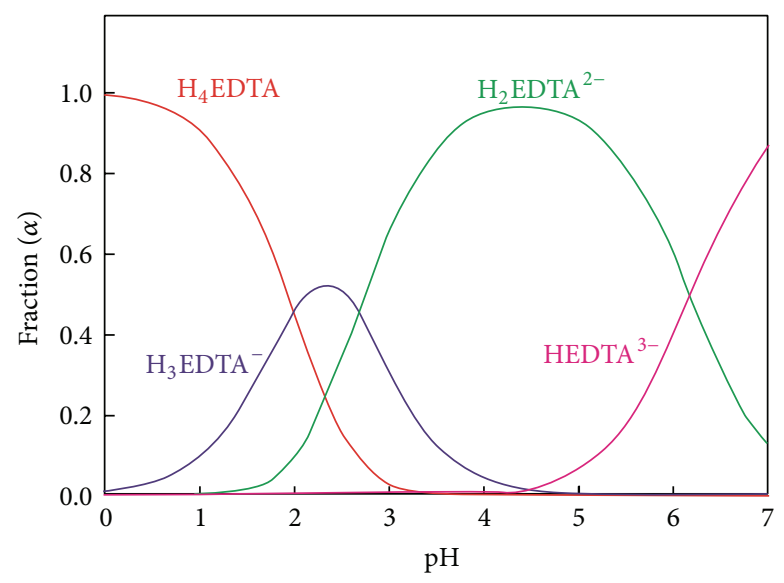

(b)

Figure 5: (a) Spectral shift of $\lambda_{\max }$ depending on [EDTA] and $\mathrm{pH}_{i}$. (b) Speciation of EDTA depending on pH. Experimental conditions: [catalyst $]=0.5 \mathrm{gL}^{-1},[\mathrm{RhB}]=20 \mu \mathrm{M},[\mathrm{EDTA}]=4 \mathrm{mM}, \mathrm{pH}_{i}=2.3$, and $\lambda>420 \mathrm{~nm}$. Samples were diluted by 3 times for the analysis. The stepwise acid dissociation constants $\left(\mathrm{p} K_{a}\right)$ of EDTA are $\mathrm{p} K_{a 1}=1.99, \mathrm{p} K_{a 2}=2.67, \mathrm{p} K_{a 3}=6.16$, and $\mathrm{p} K_{a 4}=10.26[31]$.

Figure 5(a) shows the spectral shift of $\lambda_{\max }$ depending on [EDTA] and $\mathrm{pH}_{i}$. In all cases, $\lambda_{\max }$ shifted from 556 to $499 \mathrm{~nm}$ and then remained constant. Rh-110 (the fully $\mathrm{N}$ de-ethylated form of $\mathrm{RhB}$ ) exhibits an absorption maximum at $499 \mathrm{~nm}$ [28]. Therefore, the generation of Rh-110 further confirms that $\mathrm{RhB}$ is degraded through $\mathrm{N}$-deethylation in the suspension of $\mathrm{Pt} / \mathrm{TiO}_{2} / \mathrm{Nf}$ with EDTA.

The $N$-deethylation rate, which is proportional to the $\Delta \lambda_{\max }$ rate, was greatly dependent on both [EDTA] and $\mathrm{pH}_{i}$. The $N$-deethylation at $[\mathrm{EDTA}]=4 \mathrm{mM}$ was slower than that at $[E D T A]=0.4 \mathrm{mM}$, as the reaction of $\mathrm{RhB}^{\circ+}$ with EDTA (regeneration of RhB, reaction (7)) becomes more favored than that with $\mathrm{EDTA}^{\cdot+}(\mathrm{N}$-deethylation of $\mathrm{RhB}$, reaction (8)) as the concentration of EDTA increases. On the other hand, the $\mathrm{N}$-deethylation at $\mathrm{pH}_{i}=5.0$ was faster than that at $\mathrm{pH}_{i}=2.3$ at the same [EDTA], which is related to the $\mathrm{pH}-$ dependent speciation of EDTA. At $\mathrm{pH}_{i}=5.0$, EDTA primarily exists as $\mathrm{H}_{2}$ EDTA $^{2-}$, which can be repelled from the negatively charged surface of $\mathrm{TiO}_{2}$ induced by the nafion (Figure 5(b)). On the other hand, $\mathrm{H}_{4}$ EDTA and $\mathrm{H}_{3}$ EDTA $^{-}$, which can more favorably approach the negatively charged surface, are the main species at $\mathrm{pH}_{i}=2.3$ (Figure 5(b)). Therefore, the concentration of EDTA within the nafion layer at $\mathrm{pH}_{i}=5.0$ should be lower than that at $\mathrm{pH}_{i}=2.3$ despite the concentration of EDTA added being the same. A lower concentration of EDTA within the nafion layer at higher $\mathrm{pH}$ reduces the regeneration of $\mathrm{RhB}$ and therefore enhances the degradation of $\mathrm{RhB}$. The lower production of $\mathrm{H}_{2}$ at higher $\mathrm{pH}$ (see Figure 2(a)) should also be related to the faster degradation of $\mathrm{RhB}$ at higher $\mathrm{pH}$ (see Figure 5(a)). The degradation of $\mathrm{RhB}$ reduces the number of $\mathrm{RhB}$ molecules adsorbed on the surface of $\mathrm{Pt} / \mathrm{TiO}_{2} / \mathrm{Nf}$ and eventually decreases the production of $\mathrm{H}_{2}$. Overall reactions occurring in the suspension of $\mathrm{Pt} / \mathrm{TiO}_{2} / \mathrm{Nf}$ with $\mathrm{RhB}$ and EDTA under visible light are illustrated in Scheme 1.

3.4. Long-Term Experiment. In the suspension of $\mathrm{Pt} / \mathrm{TiO}_{2} / \mathrm{Nf}$, $\mathrm{H}_{2}$ was continuously produced up to $12 \mathrm{~h}$ at $[\mathrm{RhB}]=20 \mu \mathrm{M}$ $(0.6 \mu \mathrm{mol}),[\mathrm{EDTA}]=4 \mathrm{mM}$, and $\mathrm{pH}_{i}=2.3$, although the RhB (i.e., absorbance at $\lambda=556 \mathrm{~nm}$ ) was completely removed within $4 \mathrm{~h}$ (Figure 6). This result implies that not only $\mathrm{RhB}$ but also the intermediates generated from the degradation of $\mathrm{RhB}$ can act as a photosensitizer. However, the rate of $\mathrm{H}_{2}$ production gradually decreased $(9.0 \mu \mathrm{mol} / \mathrm{h}$ for $0-3 \mathrm{~h}$, $6.4 \mu \mathrm{mol} / \mathrm{h}$ for $3-6 \mathrm{~h}, 3.6 \mu \mathrm{mol} / \mathrm{h}$ for $6-9 \mathrm{~h}$, and $2.3 \mu \mathrm{mol} / \mathrm{h}$ for 9-12 h) as RhB and its intermediates were degraded (Figure 6(a)). The degradation of $\mathrm{Rh}-110\left(\lambda_{\max }=499 \mathrm{~nm}\right)$ resulting from the complete $N$-deethylation of RhB proceeded (i.e., the absorbance at $\lambda=499 \mathrm{~nm}$ continuously decreased) after $4 \mathrm{~h}$ and was completed after $12 \mathrm{~h}$ (Figure 6(b)). In accordance with the complete degradation of $\mathrm{RhB}$ and its intermediates after $12 \mathrm{~h}$, the production of $\mathrm{H}_{2}$ stopped after $12 \mathrm{~h}$.

Using $\mathrm{Pt} / \mathrm{TiO}_{2} / \mathrm{Nf}$ under visible light, approximately $70 \mu \mathrm{mol}$ of $\mathrm{H}_{2}$ was produced and $20 \mu \mathrm{M}(0.6 \mu \mathrm{mol})$ of $\mathrm{RhB}$ and its intermediates were completely degraded over a $12 \mathrm{~h}$ period without the use of external energy or chemical oxidants (Figure 6). Although high concentrations of EDTA (millimolar levels) are required in the $\mathrm{RhB}$-sensitized $\mathrm{Pt} /$ $\mathrm{TiO}_{2} / \mathrm{Nf}$ system for the simultaneous production of $\mathrm{H}_{2}$ and degradation of $\mathrm{RhB}$, many industrial wastewaters (e.g., pulp and paper, textile, and cosmetics wastewaters) contain high concentrations of EDTA [41]. In addition, EDTA can be easily degraded through conventional biological treatment, unlike $\mathrm{RhB}[42,43]$. Therefore, the application of $\mathrm{Pt} / \mathrm{TiO}_{2} / \mathrm{Nf}$ for the simultaneous production of $\mathrm{H}_{2}$ and degradation of organic dye pollutants could become practicable by using 


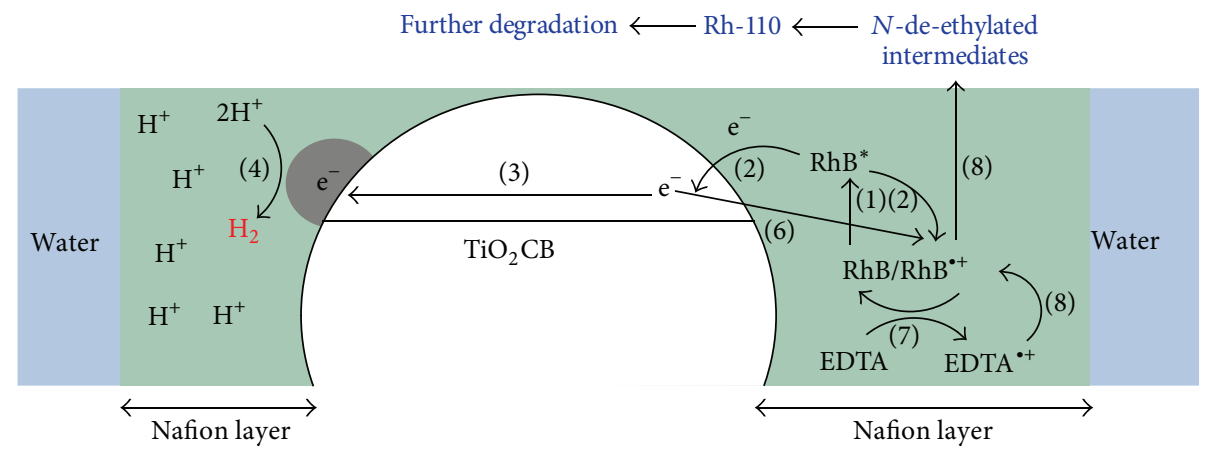

Scheme 1: Schematic illustration of the simultaneous production of $\mathrm{H}_{2}$ and degradation of $\mathrm{RhB}$ occurring on $\mathrm{Pt} / \mathrm{TiO} \mathrm{O}_{2} / \mathrm{Nf}$. (1) excitation of $\mathrm{RhB}$, (2) electron transfer from excited $\mathrm{RhB}$ to $\mathrm{TiO}_{2} \mathrm{CB}$ with $\mathrm{RhB}^{*+}$ generation, (3) electron transfer from $\mathrm{TiO}_{2} \mathrm{CB}$ to $\mathrm{Pt}$ nanoparticles, (4) reduction of protons $\left(\mathrm{H}_{2}\right.$ production), (6) electron transfer from $\mathrm{TiO}_{2} \mathrm{CB}$ to $\mathrm{RhB}{ }^{\bullet+}$ (charge recombination) with $\mathrm{RhB}$ regeneration, (7) electron transfer from EDTA to $\mathrm{RhB}^{{ }^{*+}}$ with $\mathrm{EDTA}^{\cdot+}$ generation and RhB regeneration, and (8) reaction between $\mathrm{RhB}^{\circ+}$ and $\mathrm{EDTA}^{\circ+}(\mathrm{N}$ deethylation of $\mathrm{RhB}$ ). The number in parentheses indicates the number of reactions in the text.

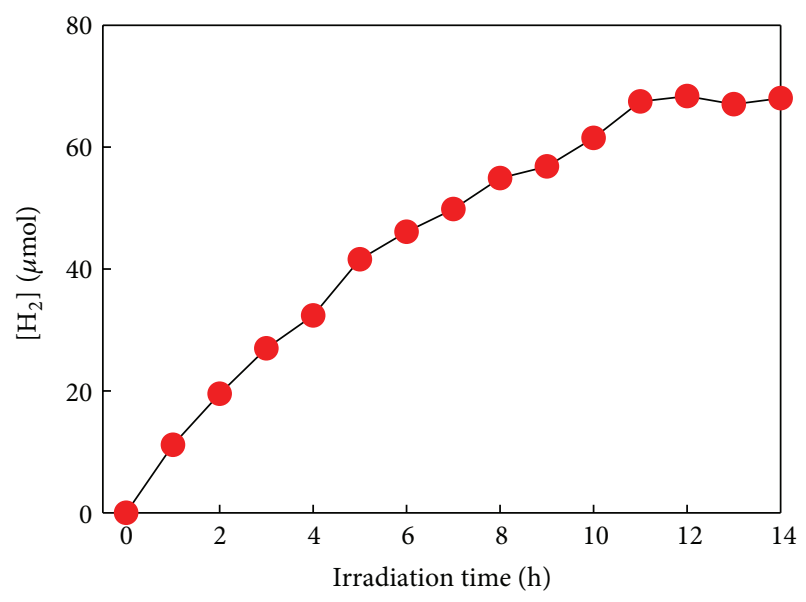

(a)

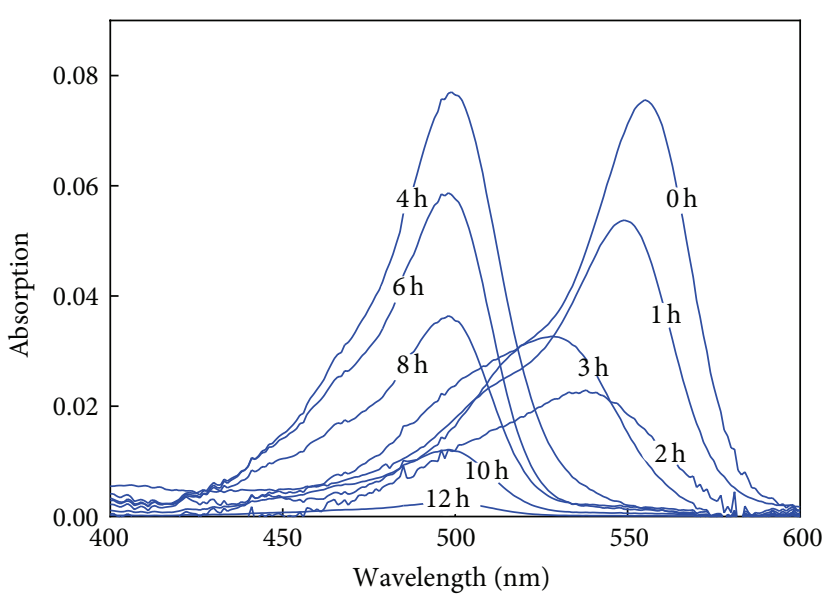

(b)

Figure 6: Long-term experiment for the simultaneous (a) production of $\mathrm{H}_{2}$ and (b) degradation of $\mathrm{RhB}$ in the suspension of $\mathrm{Pt} / \mathrm{TiO} / 2 \mathrm{Nf}$. Experimental conditions: [catalyst] $=0.5 \mathrm{~g} \mathrm{~L}^{-1},[\mathrm{RhB}]=20 \mu \mathrm{M},[\mathrm{EDTA}]=4 \mathrm{mM}, \mathrm{pH}_{i}=2.3$, and $\lambda>420 \mathrm{~nm}$. Samples were diluted by 3 times for the analysis (for part (b)).

industrial wastewaters containing high concentrations of EDTA.

\section{Conclusions}

The present study introduces a new strategy for visible-lightinduced bifunctional photocatalysis (i.e., the simultaneous production of hydrogen and degradation of pollutants) using $\mathrm{TiO}_{2}$ modified with platinum and nafion $\left(\mathrm{Pt} / \mathrm{TiO}_{2} / \mathrm{Nf}\right)$ and organic dye pollutants. In the presence of $\mathrm{RhB}$ (as both a photosensitizer and an organic dye pollutant) and EDTA (as an electron donor), $\mathrm{Pt} / \mathrm{TiO}_{2} / \mathrm{Nf}$ exhibited considerably higher activity for $\mathrm{H}_{2}$ production than $\mathrm{Pt} / \mathrm{TiO}_{2}$. This is ascribed to the negatively charged surface of $\mathrm{TiO}_{2}$ induced by the nafion, which enhances the adsorption of cationic $\mathrm{RhB}$ and pulls protons, a source of hydrogen, to the surface of $\mathrm{TiO}_{2}$. In addition, the degradation of $\mathrm{RhB}$ was accompanied by the concurrent production of $\mathrm{H}_{2}$. The intensity of the $\mathrm{RhB}$ absorption spectrum decreased and its position shifted to shorter wavelengths, which indicates that $\mathrm{RhB}$ is primarily degraded through $\mathrm{N}$-deethylation. EDTA ${ }^{*+}$, which is generated from the oxidation of EDTA by $\mathrm{RhB}^{\circ+}$, is found to be involved in the degradation mechanism, as $\mathrm{RhB}$ was not degraded in the absence of EDTA. Rh-110, a fully $N$-de-ethylated form of RhB, was further degraded and the production of $\mathrm{H}_{2}$ continued until $\mathrm{RhB}$ and its intermediates were completely degraded. Based on its high efficiency, bifunctionality, and visible light activity, this organic dye pollutant-sensitized $\mathrm{TiO}_{2}$ system using $\mathrm{Pt} / \mathrm{TiO}_{2} / \mathrm{Nf}$ can be proposed as a viable photocatalytic system for the simultaneous production of hydrogen and degradation of organic dye pollutants.

\section{Conflict of Interests}

The authors declare that there is no conflict of interests regarding the publication of this paper. 


\section{Acknowledgments}

This research was supported by Basic Science Research Program (no. 2013R1A1A1007312 and no. 2012R1A2A2A01004517), Framework of International Cooperation Program (no. 2013K2A1A2052901), Korea Center for Artificial Photosynthesis (no. 2012M1A2A2671779) through the National Research Foundation of Korea (NRF), and DGIST research program (14-EN-01) funded by the Ministry of Science, ICT \& Future Planning. Jungwon Kim is also grateful for the Hallym University Research Fund (HRF-G2013-3).

\section{References}

[1] J. W. Youngblood, S.-H. A. Lee, Y. Kobayashi et al., "Photoassisted overall water splitting in a visible light-absorbing dyesensitized photoelectrochemical cell," Journal of the American Chemical Society, vol. 131, no. 3, pp. 926-927, 2009.

[2] Y. Park, S.-H. Lee, S. O. Kang, and W. Choi, "Organic dye-sensitized $\mathrm{TiO}_{2}$ for the redox conversion of water pollutants under visible light," Chemical Communications, vol. 46, no. 14, pp. 2477-2479, 2010.

[3] J. Park, J. Yi, T. Tachikawa, T. Majima, and W. Choi, "Guanidinium-enhanced production of hydrogen on nafion-coated dye/ $/ \mathrm{TiO}_{2}$ under visible light," The Journal of Physical Chemistry Letters, vol. 1, no. 9, pp. 1351-1355, 2010.

[4] X. Zhang, U. Veikko, J. Mao, P. Cai, and T. Peng, "Visiblelight-induced photocatalytic hydrogen production over binuclear RuII-bipyridyl dye-sensitized $\mathrm{TiO}_{2}$ without noble metal loading," Chemistry - A European Journal, vol. 18, no. 38, pp. 12103-12111, 2012.

[5] M. M. Maitani, C. Zhan, D. Mochizuki, E. Suzuki, and Y. Wada, "Influence of co-existing alcohol on charge transfer of $\mathrm{H}_{2}$ evolution under visible light with dye-sensitized nanocrystalline $\mathrm{TiO}_{2}$," Applied Catalysis B: Environmental, vol. 140-141, pp. 406411, 2013.

[6] A. Kruth, S. Hansen, T. Beweries, V. Brüser, and K.-D. Weltmann, "Plasma synthesis of polymer-capped dye-sensitised anatase nanopowders for visible-light-driven hydrogen evolution," ChemSusChem, vol. 6, no. 1, pp. 152-159, 2013.

[7] W. Kim, T. Tachikawa, T. Majima, C. Li, H.-J. Kim, and W. Choi, "Tin-porphyrin sensitized $\mathrm{TiO}_{2}$ for the production of $\mathrm{H}_{2}$ under visible light," Energy \& Environmental Science, vol. 3, no. 11, pp. 1789-1795, 2010.

[8] S. K. Choi, S. Kim, J. Ryu, S. K. Lim, and H. Park, “Titania nanofibers as a photo-antenna for dye-sensitized solar hydrogen," Photochemical and Photobiological Sciences, vol. 11, no. 9, pp. 1437-1444, 2012.

[9] H. Park, Y. Park, W. Kim, and W. Choi, "Surface modification of $\mathrm{TiO}_{2}$ photocatalyst for environmental applications," Journal of Photochemistry and Photobiology C: Photochemistry Reviews, vol. 15, no. 1, pp. 1-20, 2013.

[10] W. Kim, T. Tachikawa, T. Majima, and W. Choi, "Photocatalysis of dye-sensitized $\mathrm{TiO}_{2}$ nanoparticles with thin overcoat of $\mathrm{Al}_{2} \mathrm{O}_{3}$ : enhanced activity for $\mathrm{H}_{2}$ production and dechlorination of $\mathrm{CCl}_{4}$," The Journal of Physical Chemistry $C$, vol. 113, no. 24, pp. 10603-10609, 2009.

[11] Y. Park, W. Kim, D. Monllor-Satoca, T. Tachikawa, T. Majima, and W. Choi, "Role of interparticle charge transfers in agglomerated photocatalyst nanoparticles: Demonstration in aqueous suspension of dye-sensitized $\mathrm{TiO}_{2}$," The Journal of Physical Chemistry Letters, vol. 4, no. 1, pp. 189-194, 2013.

[12] Y. Li, C. Xie, S. Peng, G. Lu, and S. Li, "Eosin Y-sensitized nitrogen-doped $\mathrm{TiO}_{2}$ for efficient visible light photocatalytic hydrogen evolution," Journal of Molecular Catalysis A: Chemical, vol. 282, no. 1-2, pp. 117-123, 2008.

[13] Y. Li, M. Guo, S. Peng, G. Lu, and S. Li, "Formation of multilayer-Eosin Y-sensitized $\mathrm{TiO}_{2}$ via $\mathrm{Fe}^{3+}$ coupling for efficient visible-light photocatalytic hydrogen evolution," International Journal of Hydrogen Energy, vol. 34, no. 14, pp. 5629-5636, 2009.

[14] X. Liu, Y. Li, S. Peng, G. Lu, and S. Li, "Photosensitization of $\mathrm{SiW}_{11} \mathrm{O}_{39}^{8-}$-modified $\mathrm{TiO}_{2}$ by Eosin $\mathrm{Y}$ for stable visible-light $\mathrm{H}_{2}$ generation," International Journal of Hydrogen Energy, vol. 38, no. 27, pp. 11709-11719, 2013.

[15] J. Xu, Y. Li, S. Peng, G. Lu, and S. Li, "Eosin Y-sensitized graphitic carbon nitride fabricated by heating urea for visible light photocatalytic hydrogen evolution: the effect of the pyrolysis temperature of urea," Physical Chemistry Chemical Physics, vol. 15, no. 20, pp. 7657-7665, 2013.

[16] V. K. Gupta and Suhas,, "Application of low-cost adsorbents for dye removal-a review," Journal of Environmental Management, vol. 90, no. 8, pp. 2313-2342, 2009.

[17] C. A. Martínez-Huitle and E. Brillas, "Decontamination of wastewaters containing synthetic organic dyes by electrochemical methods: a general review," Applied Catalysis B: Environmental, vol. 87, no. 3-4, pp. 105-145, 2009.

[18] G. Crini, "Non-conventional low-cost adsorbents for dye removal: a review," Bioresource Technology, vol. 97, no. 9, pp. 1061-1085, 2006.

[19] H. S. Rai, M. S. Bhattacharyya, J. Singh, T. K. Bansal, P. Vats, and U. C. Banerjee, "Removal of dyes from the effluent of textile and dyestuff manufacturing industry: a review of emerging techniques with reference to biological treatment," Critical Reviews in Environmental Science and Technology, vol. 35, no. 3, pp. 219-238, 2005.

[20] J. Kim and W. Choi, "Hydrogen producing water treatment through solar photocatalysis," Energy and Environmental Science, vol. 3, no. 8, pp. 1042-1045, 2010.

[21] J. Kim, D. Monllor-Satoca, and W. Choi, "Simultaneous production of hydrogen with the degradation of organic pollutants using $\mathrm{TiO}_{2}$ photocatalyst modified with dual surface components," Energy and Environmental Science, vol. 5, no. 6, pp. 76477656, 2012.

[22] W. Zhang, Y. Li, C. Wang, P. Wang, and Q. Wang, "Energy recovery during advanced wastewater treatment: simultaneous estrogenic activity removal and hydrogen production through solar photocatalysis," Water Research, vol. 47 , no. 3, pp. 1480 1490, 2013.

[23] W. Zhang, Y. Li, C. Wang, P. Wang, Q. Wang, and D. Wang, "Mechanisms of simultaneous hydrogen production and estrogenic activity removal from secondary effluent though solar photocatalysis," Water Research, vol. 47, no. 9, pp. 3173-3182, 2013.

[24] Y. Li, G. Lu, and S. Li, "Photocatalytic hydrogen generation and decomposition of oxalic acid over platinized $\mathrm{TiO}_{2}$," Applied Catalysis A: General, vol. 214, no. 2, pp. 179-185, 2001.

[25] Y. Li, Y. Xie, S. Peng, G. Lu, and S. Li, "Photocatalytic hydrogen generation in the presence of chloroacetic acids over $\mathrm{Pt} / \mathrm{TiO}_{2}$," Chemosphere, vol. 63, no. 8, pp. 1312-1318, 2006.

[26] Y. Li, K. Zhang, S. Peng, G. Lu, and S. Li, "Photocatalytic hydrogen generation in the presence of ethanolamines over $\mathrm{Pt} / \mathrm{ZnIn}_{2} \mathrm{~S}_{4}$ 
under visible light irradiation," Journal of Molecular Catalysis A: Chemical, vol. 363-364, pp. 354-361, 2012.

[27] H. Park and W. Choi, "Visible-light-sensitized production of hydrogen using perfluorosulfonate polymer-coated $\mathrm{TiO}_{2}$ nanoparticles: an alternative approach to sensitizer anchoring," Langmuir, vol. 22, no. 6, pp. 2906-2911, 2006.

[28] H. Park and W. Choi, "Photocatalytic reactivities of nafioncoated $\mathrm{TiO}_{2}$ for the degradation of charged organic compounds under UV or visible light," Journal of Physical Chemistry B, vol. 109, no. 23, pp. 11667-11674, 2005.

[29] C. Chen, W. Zhao, P. Lei, J. Zhao, and N. Serpone, "Photosensitized degradation of dyes in polyoxometalate solutions Versus $\mathrm{TiO}_{2}$ dispersions under visible-light irradiation: mechanistic implications," Chemistry - A European Journal, vol. 10, no. 8, pp. 1956-1965, 2004.

[30] Y. Li, G. Lu, and S. Li, "Photocatalytic transformation of rhodamine $\mathrm{B}$ and its effect on hydrogen evolution over $\mathrm{Pt} / \mathrm{TiO}_{2}$ in the presence of electron donors," Journal of Photochemistry and Photobiology A: Chemistry, vol. 152, no. 1-3, pp. 219-228, 2002.

[31] J.-L. Burqot, Ionic Equilibria in Analytical Chemistry, chapter 28, Springer, New York, NY, USA, 2012.

[32] A. Yamakata, T.-A. Ishibashi, and H. Onishi, "Water- and oxygen-induced decay kinetics of photogenerated electrons in $\mathrm{TiO}_{2}$ and $\mathrm{Pt} / \mathrm{TiO}_{2}$ : a time-resolved infrared absorption study," The Journal of Physical Chemistry B, vol. 105, no. 30, pp. 7258-7262, 2001.

[33] J. Kim, J. Lee, and W. Choi, "Synergic effect of simultaneous fluorination and platinization of $\mathrm{TiO}_{2}$ surface on anoxic photocatalytic degradation of organic compounds," Chemical Communications, no. 6, pp. 756-758, 2008.

[34] H. Park, Y. Park, E. Bae, and W. Choi, "Photoactive componentloaded Nafion film as a platform of hydrogen generation: alternative utilization of a classical sensitizing system," Journal of Photochemistry and Photobiology A: Chemistry, vol. 203, no. 2-3, pp. 112-118, 2009.

[35] D. Vasudevan and A. T. Stone, "Adsorption of catechols, 2-aminophenols, and 1,2-phenylenediamines at the metal (hydr)oxide/ water interface: effect of ring substituants on the adsorption onto $\mathrm{TiO}_{2}$," Environmental Science and Technology, vol. 30, no. 5, pp. 1604-1613, 1996.

[36] S. J. Sondheimer, N. J. Bunce, and C. A. Fyfe, "Structure and chemistry of nafion-H: a fluorinated sulfonic acid polymer," Journal of Macromolecular Science - Reviews in Macromolecular Chemistry and Physics, vol. 26, no. 3, pp. 353-413, 1986.

[37] G. V. Buxton, C. L. Greenstock, W. P. Helman, and A. B. Ross, "Critical review of rate constants for reactions of hydrated electrons, hydrogen atoms and hydroxyl radicals $\left(\cdot \mathrm{OH} / \cdot \mathrm{O}^{-}\right.$in aqueous solution," Journal of Physical and Chemical Reference Data, vol. 17, no. 2, pp. 513-886, 1988.

[38] T. Wu, G. Liu, J. Zhao, H. Hidaka, and N. Serpone, "Photoassisted degradation of dye pollutants. V. Self-photosensitized oxidative transformation of Rhodamine $B$ under visible light irradiation in aqueous $\mathrm{TiO}_{2}$ dispersions," The Journal of Physical Chemistry B, vol. 102, no. 30, pp. 5845-5851, 1998.

[39] H. W. Jeong and H. Park, "Carbon-catalyzed dye-sensitization for solar hydrogen production," Catalysis Today, vol. 230, pp. 15-19, 2014.

[40] B. Höbel and C. Von Sonntag, "OH-Radical induced degradation of ethylenediaminetetraacetic acid (EDTA) in aqueous solution: a pulse radiolysis study," Journal of the Chemical Society, Perkin Transactions, vol. 2, no. 3, pp. 509-513, 1998.
[41] B. Eklund, E. Bruno, G. Lithner, and H. Borg, "Use of ethylenediaminetetraacetic acid in pulp mills and effects on metal mobility and primary production," Environmental Toxicology and Chemistry, vol. 21, no. 5, pp. 1040-1051, 2002.

[42] U. Kaluza, P. Klingelhöfer, and K. Taeger, "Microbial degradation of EDTA in an industrial wastewater treatment plant," Water Research, vol. 32, no. 9, pp. 2843-2845, 1998.

[43] B. Nörtemann, "Total degradation of EDTA by mixed cultures and a bacterial isolate," Applied and Environmental Microbiology, vol. 58, no. 2, pp. 671-676, 1992. 

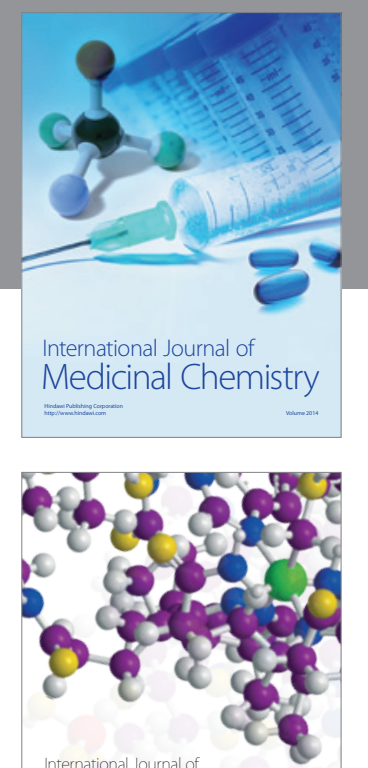

\section{Carbohydrate} Chemistry

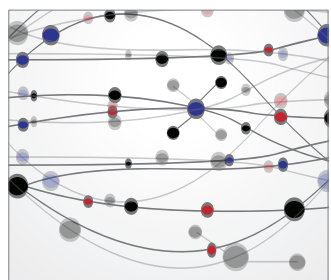

The Scientific World Journal
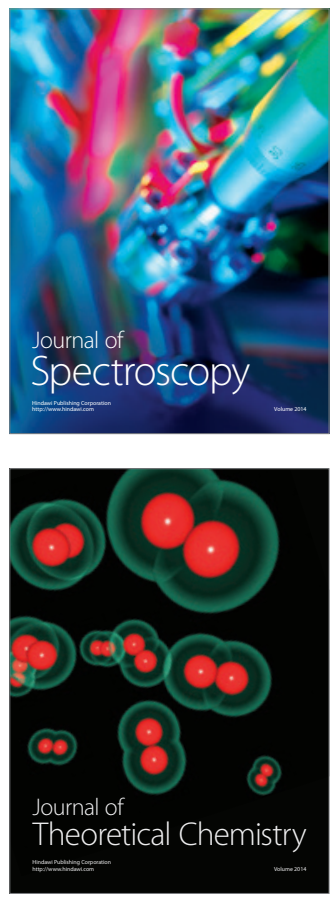
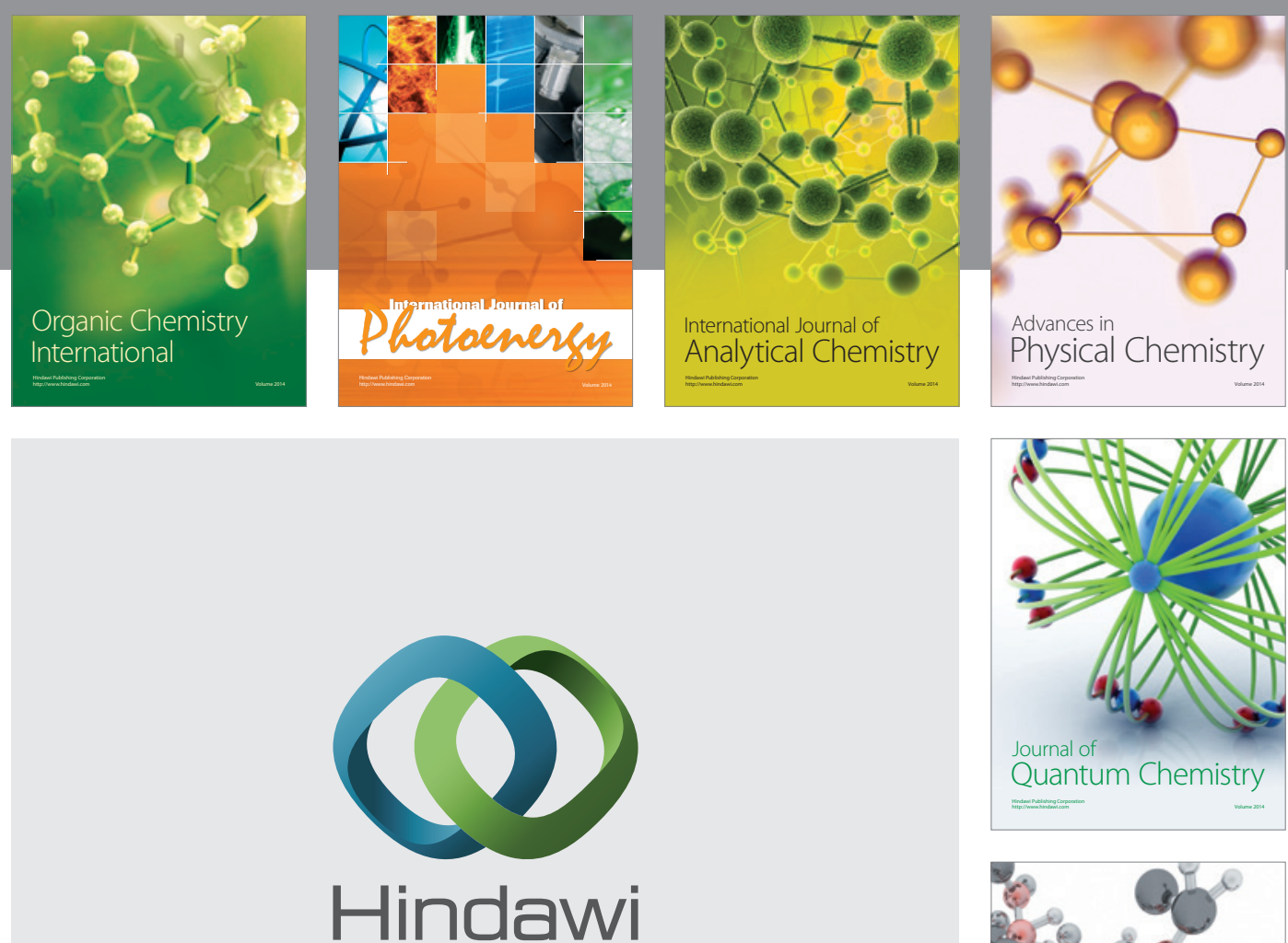

Submit your manuscripts at

http://www.hindawi.com

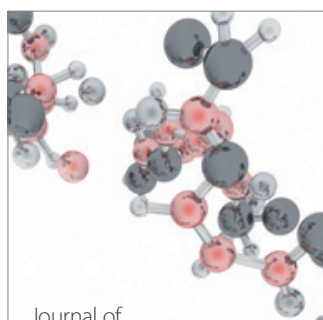

Analytical Methods

in Chemistry

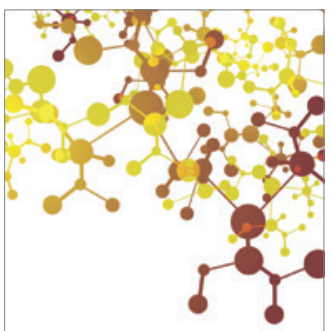

Journal of

Applied Chemistry

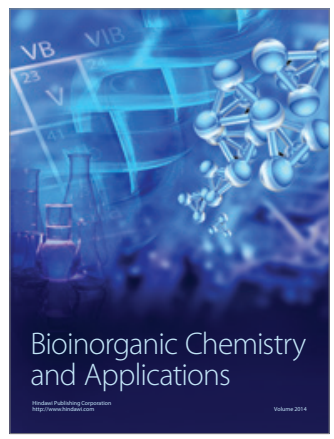

Inorganic Chemistry
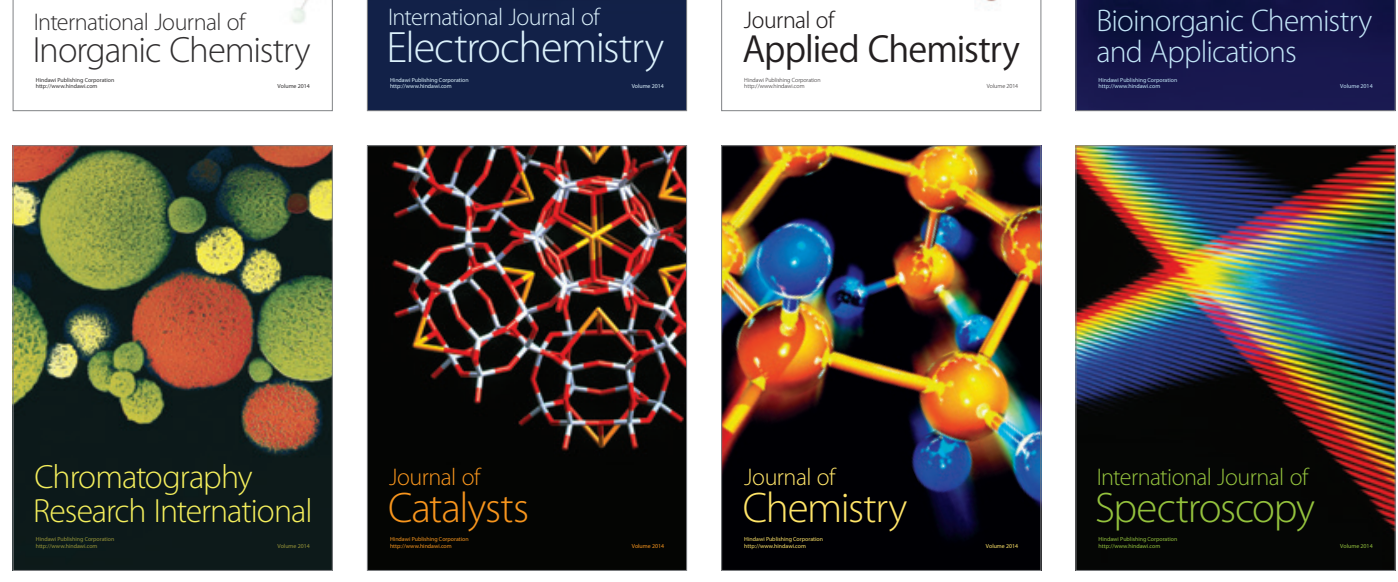